\title{
A Prince of Asturias Award for the Queen of Canadian Letters: Reading Margaret Atwood's Texts in Spain
}

\author{
Pilar Somacarrera
}

\section{The Story of Atwood's Translations in Spain}

In an interview with Geoff Hancock (1987), Margaret Atwood expressed her concern about how her books were read in the countries where they were being translated: "I'm now translated into over twenty languages, only two of which I can read, more or less. I have no idea what those other versions are saying to the people who read them. ${ }^{105}$ Atwood is making a crucial reflection about how her writing acquires a new life once it has been translated into another language and exported into a different culture, a process which requires favourable economic, sociological and political conditions. In a more recent interview held in Spain, she acknowledges that her own books could not be imported to the country when she started publishing (late sixties-early seventies) because of the ideological repression of the Franco regime: "During the Franco years it was difficult for [her] books to be translated in Spain, as they were considered too radical. Or, they often appeared first in other Spanishspeaking countries such as Argentina" (Stone, 2006). Surely she could hardly imagine at the time that in 2008 she would receive the Prince of Asturias Award, one of the greatest literary honours of the same country where her books would have been forbidden or censored twenty years before. In this chapter I would like to explore two aspects of how Margaret Atwood's texts are read in Spain. First, I will analyze the factors which have influenced the Spanish transference of her writing - the books chosen for translation and the translators and publishing houses in charge of them. Secondly, I will consider the way in which what Richard Dyer (1979) calls the "star text" of her literary celebrity has been read in Spain through the study of reviews, articles, notes and interviews published in the written press. ${ }^{106}$

105 Atwood (2009) has not disguised her scepticism about the activity of translation itself, especially with poetic texts. At the videoconference she held with the Spanish press for the launching of The Door on February 2, 2009, she argued that poetry is the most difficult genre to translate and praised her translators as "courageous," because the rhythm and music of poetry are always language-specific.

106 All translation of the articles and reviews are mine. 
The process of transference of a new writer into a target language often resembles a narrative in which the characters are authors, translators, publishers, editors, readers, publicity officers, reviewers, and cultural and political institutions. In a review of Atwood's novels Lady Oracle and The Robber Bride, María José Obiol (1996b) narrativizes the story of how the Canadian writer started to be published in Spain: "It was in 1987 when the word of Margaret Atwood came to this country in a novel recreating a future in which women had lost control over their bodies. The title of this disturbing parable about the future was The Handmaid's Tale." Its publication had been preceded and accompanied by a various references to Atwood in the Spanish press, first as an internationally acclaimed writer who had been elected President of PEN International in 1984, and later as a candidate for the Nobel Prize for literature. Twelve years after Franco's death, Catalan publisher Seix Barral released the novel as part of its emblematic collection Biblioteca Breve (Brief Library). As the Catalan editor Esther Tusquets (2009) recounts in her book of memoirs, during the years of Franco's dictatorship Seix Barral and his director Carlos Barral played a crucial role in introducing relevant foreign authors in Spain (228-29). Given Seix-Barral's publishing history, surely The Handmaid's Tale was not a random choice (Azancot, 2011). The novel accumulated a number of assets. Firstly, as "a disturbing parable about the future" (Obiol, 1996b), it could be included in the category of speculative fiction - in Spanish, novela de anticipación (Morreres i Boix, 1987)107 - a genre mostly absent from the Spanish literary system at the time but with considerable market possibilities because of its numerous followers. Secondly, it was written by a woman, which was perceived as unusual for this kind of novel. Thirdly, drawing on the cosmpolitanizing technique which Nieves Pascual calls an "emphasis on vitality and tradition," 108 Aldous Huxley and George Orwell were invoked as its intertexual referents. ${ }^{109}$ Fourthly, it touched on the then current debates kindled by a document released by The Vatican about reproduction in vitro (Morreres i Boix, 1987). ${ }^{110}$ It had won several international awards - the Governor's General Award in 1985 and the Arthur C. Clarke Award for Science

107 Morreres i Boix uses this term to refer to The Handmaid's Tale ("obra de anticipación") and mentions a novel of this genre, Andrea Victrix (1974), written in Catalan by Llorenç Villalonga, under the influence of Aldous Huxley.

108 See chapter 2 of this volume.

109 These authors are mentioned in the "epitext" or publicity material published by the press.

110 In 1987 Spain was ruled by the second socialist government of Félipe González, who had passed the Abortion Law in 1985, not without polemical reactions among the most right-wing sectors of society, inheritors of Franco's conservative views about the family. 
Fiction in 1987. Finally, the famous playwright Harold Pinter was writing the script for a film about it, as noted in an article written to publicize the launching of the novel at the edition of the Madrid Book Fair in 1987 (De León-Sotelo, 1987). Interestingly, the setting of the novel was not Canada but the United States, a country that most Spaniards would recognize as the birth-place of modern democracy.

In María José Obiol's version, the story of Margaret Atwood's books in Spain continues with the market success of The Handmaid's Tale ${ }^{111}$ which excited readers' interest and made them "wait for more novels from this Canadian writer to fill their personal literary pantries (Obiol, 1996b). "They did not have to wait very long, as her books started to appear regularly in Spain: between 1987 and 1996 five novels and one collection of short stories were published in Spain. ${ }^{112}$ During this decade (1987-1996), the trend was to publish a recent title and one title from the back list. In addition, the time between the publication of Atwood's titles gradually reduced. Since 2000 , the tendency is that the Spanish translation of a new novel by Atwood appears the year after the original. Two years later, The Handmaid's Tale was followed by the short story collection Bluebeard's Egg (published originally in 1983), then by Cat's Eye in 1990, next in the list of Atwood's novels after The Handmaid's Tale.

Atwood's poetry entered Spain with The Journals of Susanna Moodiel Los diarios de Susana Moodie ${ }^{113}$ (1991), a text of marked Canadian content contrasting with the feminist bias of the fiction that had been published before. The Canadian content of the collection (about an English woman pioneer struggling in the Canadian wilderness) was most probably missed by the Spanish reader because the text was published without Atwood's Afterword, which gives essential clues about the significance of the figure of Susanna Moodie for Margaret Atwood and for Canadian culture in general (Somacarrera, 2005). ${ }^{114}$ Also related to Canada's image as a Northern country is the publication of the story "The Age of Lead"/"La edad de plomo" in Spanish translation, containing

$\mathbf{1 1 1}$ The book was reprinted again in the year of its first publication and, subsequently four more times, two of these immediately after Atwood won the Booker and the Asturias Prizes.

$\mathbf{1 1 2}$ See the chronology of the publication of Atwood's books in Spain, as well as of events related to her presence in country at the end of this chapter.

113 The text could have been chosen because of its unquestionable position in the Canadian literature canon (Surette, 1995).

$\mathbf{1 1 4}$ To this day, the reason why the collection was published without Atwood's Afterword remains a mystery. In a personal conversation, Alberto García, one of the translators of the book, revealed that the publisher had sent them Atwood's poems without the Afterword. The passage from Atwood's Afterword which deals with schizophrenia as Canada's mental illness has been translated by Somacarrera (2000). 
a reference to a TV documentary describing the death of John Torrington, a young sailor of the ill-fated Franklin expedition to find the Northwest Passage in 1845. The story was published in issue number 139 (December 1992) of the renowned journal Revista de Occidente. ${ }^{115}$ dedicated to "Contemporary Women Authors," together with other stories by women writers like Angela Carter, Helia Correia and Elena Poniatowska. The publication of Atwood's story in Revista de Occidente as an example of "the attractive panorama of contemporary feminine literature" ("Revista de occidente," 1992) signifies an important step in the process of Atwood's admission to a cosmopolitan and avant-garde Spanish canon of women writers.

In 1994, along the same cosmopolitan vein, the publisher Muchnik Editores, directed by the Argentinian editor Mario Muchnik, published Surfacing in a translation by Ana Poljak, twenty-two years after its original publication in 1972. Its publication in Spain may probably be related to Harold Bloom's inclusion of the novel as one of the Canadian books of his Western canon in the same year. Ten years later there was a retranslation of this novel by Gabriela Bustelo in charge of another reputable Spanish publisher, Alianza Editorial, only two years after Harold Bloom's The Western Canon had finally been published in Spain in 2002. The imprint chosen for publication in 2004 was Libro de Bolsillo (Pocket Book), aiming, perhaps, at a wider readership. Following the Prince of Asturias Award in 2008, Alianza Editorial reprinted the novel in its more expensive imprint Alianza Literaria, aimed at a "higher-brow" audience (cover price of $18.50 €$, as opposed to $8.50 €$ of the Pocket Book edition). This edition presents a more sophisticated cover design and a blurb referring to Bloom's canonization of Atwood's novel, describing it as "one of the fundamental and most influential works of our culture" (Alianza Editorial, "Promotional synopsis." The covers of both editions of Surfacing published by Alianza Editorial emphasize its Canadian setting, presenting Canada, not as it really is - a country of urban-dwellers -, but as a wilderness territory of breath-taking natural beauty, full of lakes and mountains. In accordance with Anna M. Gil's (1996) summary of the novel as a return to the North of the Great Lakes, an area of trappers, lumberjacks and hikers, the Pocket Book edition shows a landscape which evokes the Northern Quebec area where the novel is set. The Alianza Literaria edition displays a landscape evoking that of the Canadian Rocky Mountains, a touristic setting which is probably better known to Spanish readers. ${ }^{116}$

115 Founded in 1923 by the famous Spanish philosopher José Ortega y Gasset and now directed by his grandson, José Valera Ortega, Revista de Occidente aims at "paying attention to the most innovative currents in thought as well as in artistic and literary creation (See Fundación Ortega-Marañón).

$\mathbf{1 1 6}$ The covers for both editions can be seen at the Alianza Editorial webpage. 
Between 1996 and 2000, three more novels (Lady Oracle, The Robber Bride and Alias Grace) and one short story collection (Dancing Girls) were published. Atwood visited Madrid to promote Alias Grace in 1998, addressing a full room of readers at the Círculo de Bellas Artes, a famous cultural institution of Madrid, in a lecture series called "Canadian Women Writers of the Turn of the Century" organized by the Canadian Embassy. The years between 1998 and 2003 marked a peak in her popularity among the Spanish readership. It coincided with a period when the Spanish Association for Canadian Studies was particularly active, and when the dissemination of her works received strong institutional support from the Canadian Mission. Partly as a result of the aforementioned factors, she received much attention from the media and appreciation from her Spanish readers, mostly middle-class women with a high level of education and between the age range of 20 and $50 .{ }^{117}$ Since Atwood received the Man Booker Prize in 2000 for The Blind Assassin, published in Spain in 2001, the pace of publication of her work increased to at least one book a year, keeping up this rate until the time of writing this essay. All her novels have been published in Spanish except Life Before Man (1979) and Bodily Harm (1981).

Encouraged by the popularity of her fiction and the prestige conferred upon her by the Booker, publishers have ventured to release titles from other genres practised by Atwood. Lumen, now an imprint of Random House Mondadori, published a sample of her essays as La maldición de Eva in 2006. Two of her children's books were published in 2008: Anna's Pet (in Catalan) and Up in the Tree (in Catalan and Spanish). In 2011 the outcome of Ana María Moix's last collaboration with Bruguera, the non-fiction volume Payback/ Pagar (con la misma moneda) was published in a translation by Ana Becciu.

Four of her poetry collections have appeared in Spain in three different stages, separated by an interval of approximately a decade. After the first poetry collection (Los diarios de Susanna Moodie) appeared in 1991, Power Politics and Interlunar became available in 2000 , edited by two prestigious publishers specializing in poetry (Hiperión and Icaria). Considered by some critics as the only poetry collection by Atwood to have had a certain impact on the Spanish readership, ${ }^{118}$ Power Politics/ Juegos de Poder appeared on the fifth position of the chart of bestselling poetry books of the cultural supplement of $A B C$ ( "Libros más vendidos," 2000).

117 Many of Atwood's Spanish readers are female university students who have read her, mostly in English, in courses about CanLit or about other subjects taught in Spanish universities.

118 See the report of the videoconference organized for the launching of The Door published in El Mundo. Its sensationalistic title was "'If the human being is scared, he is capable of anything" (Plaza, 2009). 
In the third and latest stage of the Spanish publication of Atwood's poetry, Bruguera released two volumes in two years: The Door (2007)/ La puerta, her latest poetry collection in 2009, and a year later, True Stories (originally published in 1981). As the first book to be published after Atwood had received the Prince of Asturias Award, The Door was marketed in a way unusual for a poetry collection, including a videoconference held in February 17, 2009 with the author speaking live from Toronto. This spectacular launching strategy, suggested by Atwood herself ${ }^{119}$ and in which Bruguera had invested most of its publicity budget for that year, resulted in massive attention on the part of the press with notes and articles too numerous even to attempt to mention them here. However, it did not have a significant impact on the sales of The Door possibly because of intrinsic reasons - the content and tone of the collection, focusing on autobiographical and philosophical themes, rather than on the more popular feminist preoccupations of Power Politics -, as well as external ones - the recession that had started to hit the Spanish book market in 2008.

Atwood's Spanish publishers have been her prestigious sponsors, adding cultural capital to her qualities as a writer. Victor Pozanco, poet and translator of Dancing Girls for Lumen, has rightly observed that it has been the publishers with most sensitivity for great literature who have included Atwood in their catalogues. He tells the anecdote of how Esther Tusquets, director of Lumen, had offered him the translation of another potential Nobel Prize, saying that Atwood "was not a Nobel Prize-winner yet, but would be one day (Pozanco, 2008). KRK, a small independent press based in Oviedo published Asesinato en la oscuridad (Murder in the Dark and Good Bones) following the initiative of Professor Isabel Carrera of the University of Oviedo, who did the translation herself. However, the rights of this book were soon ceded to Ediciones $B$ who produced a different selection of the stories in 2005. This press belonging to the media group Zeta has published all the titles of Atwood's fiction since 1998 and in 2008, under Ana Maria Moix's direction of its imprint Bruguera, ${ }^{120}$ also acquired the preference to publish her poetry. Moix's project was to publish the entire backlist of Atwood's poetry collections but, sadly, the closure of Bruguera has left her project unfinished.

If her publishers have played an important role in the transference of Atwood's works in Spain as patrons who, following André Lefevere (1992) are outside the literary system, no less crucial have been her translators, as professionals within

119 Atwood herself had suggested this way of launching the book at the dinner organized in her honour by the Canadian Mission in Spain for the presentation of the Prince of Asturias Award (October 23, 2008).

$\mathbf{1 2 0}$ For the history of this emblematic imprint, see chapter 1 of this volume. 
the literary system. A good translation always implies collaboration between translators and editors although the vagaries of how these translators are chosen by publishers are too complex to be addressed in a study like this. Twenty-three different translators have translated Atwood into Spanish versions and into Catalan. Five of them have worked on more than one book: Jordi Mustieles (Cat's Eye and The Robber Bride), Juanjo Estrella (The Edible Woman and Oryx and Crake), María Antonia Menini (Alias Grace and Murder in the Dark), Victor Pozanco (Chicas Bailarinas and Érase una vez, both containing stories from Dancing Girls) and Pilar Somacarrera (Power Politics, True Stories and The Door).

Arnulf Conradi, Atwood's German publisher, is of the view that the success of Atwood's books in Germany has to do with her having had the same translator (Brigitte Walitzek) for several of her books (Conradi, 2000). I agree with Conradi that when the same translator produces more than one translation by the same author, the resulting work is usually stylistically coherent and adapted to the requirements of the target readership whose responses they have also come to know over the years of translating the same author. In the Spanish list of Atwood's translators, we find writers and poets (Luis Marigómez, Gabriela Bustelo and Victor Pozanco), university teachers (Isabel Carrera, Lidia Taillafer, Pilar Somacarrera), translators who have been in charge of some of recent bestsellers (Juanjo Estrella of The Da Vinci Code and Gemma Rovira of the Harry Potter series), and even one who has received the National Prize of Translation for a lifetime career in 2009 (Roser Berdagué, translator into Catalan). Some of these translators (Carrera, Pozanco, Marigómez and Somacarrera) have referred to their personal enjoyment in translating Atwood's texts (Pozanco, 2008). They have also acted as commentators, critics and preface writers, thus showing their personal involvement in the role of sponsoring Atwood and conferring upon her further symbolic capital.

\section{Reviews of Margaret Atwood's Works in the Spanish Press}

In the second section of this chapter, I will look into the role of literary reviews published in the printed press in the canonization or deprecation of Atwood's work, and try to determine to what extent these written reports contribute to her integration into the dominant poetics of Spanish culture. Because of space restrictions, I will focus on a selection of the reviews of three novels - The Handmaid's Tale, Surfacing and The Blind Assassin -which form a basic Atwood canon. Although I agree with Graham Huggan (2001) that Atwood cannot be considered an alternative writer, she was originally imported into Spain as such. As I stated in the previous section, with The Handmaid's Tale Atwood was 
transferred into the Spain of the late eighties as a marketable writer associated with timely antihegemonic and transgressive ideological tenets. It was a novel set in a dictatorship - a setting that could well evoke Spain's recent past - belonging to the genre of speculative fiction, written by a woman, and dealing with the topic of alternative ways of human reproduction. But from this peripheral position as a genre fiction writer, Atwood has slowly entered the centre of the Spanish literary system through a number of initiatives (editorial and/or institutional) that have conferred symbolic capital on her, like the previously mentioned inclusion of one of her short stories in Revista de Occidente. Most significant was her participation, under request, in the volume Don Quijote alrededor del mundo/ Don Quixote Around the World, published in 2005 by the Cervantes Institute to celebrate the 500th anniversary of Don Quixote. The book featured a preface by Harold Bloom and essays by writers who had received - or would receive in subsequent years - the Nobel or Asturias Prizes. ${ }^{121}$

As Rien T. Segers (1991) points out, a literary review is a sort of frozen, more or less structured, reading experience, the result of a specific reading process which attempts to cover newly published texts as pieces of news, worthy of reader consideration and attention. I would add that reviews are, in a more or less explicit way, instruments for marketing a book. ${ }^{122}$ Given that the attachment of meaning and value is a culturally determined activity (Segers, 1991, reviews are a useful way of gauging the responses of readers of a specific reading community, in this case the Spanish one. This community will include different types of readers to whom the publishers want to reach out: those who read the book for mere entertainment, those who look for some literary quality and, finally, academic readers. Although some of her first reviewers were anonymous, literary reviews and criticism of Margaret Atwood's books published by Spanish presses have gradually increased with time, keeping pace with her growing presence and popularity. Atwood's greater visibility in Spain, along with the various prizes she has received, could explain the multiplication of reviews.

The symbolic capital of many of her reviewers is similar to that of some her translators. In fact, as mentioned before, in some cases her translators

121 Among other writers, the volume features J.M.C. Le Clézio (Nobel Prize in 2008), Nélida Piñón and Ismail Kadaré (predecessor and successor of Atwood in the Asturias Prize, respectively).

122 Atwood herself has written numerous book reviews in which we find invaluable information about her own literary taste and about her own writing. Atwood's reviews have also played an important role in the promotion of many writers, Canadian and international. The reviews included in her collections Second Words and Moving Targets may serve as an example. 
have reviewed her work. In a critical context such as that of Spanish literary supplements, where reviewers are not often well-informed enough about Canadian literature, it does not seem surprising that the press would ask Atwood's translators for articles or even reviews of her works.

Otherwise, Atwood's reviewers have been Spanish academics, writers and publishers who, sometimes, hold more than one of these positions. José Antonio Gurpegui (a professor of US literature and Director of the Franklin Institute for American Studies at the University of Alcalá de Henares in Madrid), who regularly writes reviews for El Mundo, has reviewed all of Atwood's fiction titles since Cat's Eye. Among other Spanish writers who have also acted as Atwood's critics for the press, we can list Laura Espido Freire, Rafael Reig, José Ma Guelbenzu, Ana Maria Moix and Antonio Muñoz Molina. All of them are well-known writers and the last two have also held positions at institutions which form part of the Spanish cultural scene and which have played an important part in the dissemination of Atwood's works: Moix as Atwood's editor in Bruguera, and Múñoz Molina as director of the Cervantes Institute in New York. Other professional reviewers have written all the reviews of Atwood's texts for a newspaper, as is ithe case of Robert Saladrigas for La Vanguardia, a fact which gives coherence and continuity to the critical discourse about the Canadian writer.

There are two repetitive arguments deployed to praise Margaret Atwood in the Spanish press. The first is that she is the most important Canadian writer, and the second that she is a winner of numerous literary honours and a permanent candidate for the Nobel Prize. ${ }^{123}$ These two superlatives need to be placed in perspective because, as Graham Huggan points out, this representative status has been enhanced by the wrong view that Atwood is one of the few Canadian writers who really matter, and that Canada's is, after all, a minor literature/culture in terms of world standards (Huggan, 2001). Drawing, perhaps, on this prejudice against Canadian literature, writer and critic Valentí Puig, in a review of Cat's Eye (1990), contests Atwood's canonical status as well as her permanent condition of Nobel Prize candidate. Puig (1990) ranks Atwood among the three most relevant Canadian writers, together with Mordecai Richler and Robertson Davies, but, out of the three, he considers Davies as the only "occasional candidate to the Nobel Prize" (Puig, 1990). Puig values Davies over Atwood because, as he writes in his prologue to the Spanish edition of Fifth Business/ El quinto en discordia, "some of his novels had been translated into Spanish, but did not appeal to the fervour of masses nor to the enthusiasm of critics who still read" (2006). When he wrote his prologue to the Spanish translation of Davies's novel in 2006,

123 See, for example, the following reviews of her latest novels published in newspapers of different political orientation: Velasco (2004) and Barrios (2010). 
Puig could possibly be referring to Atwood when he spoke about writers who provoke "the fervour of masses," and "the enthusiasm of critics." because he had described her as a popular author in reviews he had written about her in the nineties, like the previously mentioned review of Cat's Eye. However, he also claims in his review of Cat's Eye that in contrast with Davies, Atwood "took off as a writer who gathered prestige and sales, a peculiar species common in the Anglosaxon world" (Puig, 1990). He then questions the canonical value of Cat's Eye, describing it as "not one of those novels one would choose for the library of a desert island."

Atwood is also often disfavoured in comparisons with Alice Munro, Margaret Laurence and Mavis Gallant. In a review of Surfacing, Alicia Giménez Bartlett, a Spanish author of detective novels and recent winner of the prestigious Nadal Prize, reveals that "she had always thought of Atwood as a writer who had been overestimated by the critics, and lacking the authenticity and sensibility of Margaret Laurence, who is, however, much less famous" (Giménez Bartlett, 1994). In a review of the Spanish translation of Mavis Gallant's Selected Stories, the writer Rosa Montero (2010) claims that she considers Gallant a much more interesting writer than the "icy" Margaret Atwood, the permanent Canadian candidate for the Nobel Prize. The main difference between Gallant and Munro and Atwood can be found in their use of genre. Whereas the first two authors practise the short story almost exclusively, Atwood moves comfortably across genres, a fact which has also contributed to raise her cultural capital. To use her first translated novel in Spain as an example, The Handmaid's Tale, because of the different genres it encapsulates - as a classic work of feminist polemic, of dystopian literature or of science fiction - can be incorporated into different canons (Huggan, 2001). Genres function as "horizons of expectations" (Jauss, 1992) for readers and "models of writing" (Todorov, 1990) for authors, but Atwood skilfully plays with them to break readers' expectations in her novels and The Handmaid's Tale is no exception. Genre can also be used as a "selling" feature because, as Claire Squires (2007) points out, it becomes a mutable and dynamic property of its marketing.

Spanish reviewers have included The Handmaid's Tale in both the categories of utopia and dystopia. The first term is used to refer to a genre in which an ideal society is depicted, whereas dystopia has been used to designate an antiutopia, a place marked by extreme mechanization or authoritarianism (Beckson and Ganz, 1989). Although the second term (dystopia) describes the content of Atwood's novel more accurately, an anonymous reviewer in a brief article titled "Slavist society based on reproduction" published in La Vanguardia before the novel was even translated, classifies it within the genre of utopia. However, he makes a distinction between Atwood's novel and those of "the English gentlemen Wells, Huxley and Orwell" ("Sociedad esclavista," 1986). When he argues that the main element the novel is the issue of reproduction (unlike the works of Wells, Huxley and Orwell), he thus contradicts the strategy of marketing that the 
Spanish publisher of the novel will undertake - the comparison of Atwood with the English masters of dystopias. The reviewer of $A B C$-equally anonymous- also contradicts the publicity campaign of the publisher, warning the readers that the novel is not a utopia in Thomas More's style nor - in spite of the publicity in Orwell's mode, because the feminine condition of the writer informs it with "idiosyncratic characteristics" ("El cuento de la criada," 1987).

Like The Handmaid's Tale, the Booker Prize-winning The Blind Assassin is described by Spanish reviewers as a compendium of a variety of genres, all of which are commercially successful: gothic, science fiction, realist novel, melodrama, harlequin romance, thriller with a touch of love story, journalism. In his suggestively titled review "Las sombras del pasado"/ "The shadows of the past," Mauricio Bach (2001) notes that whereas the protagonist's political ambitions sometimes recall the script of Dallas or Dynasty, the novel also contains an account of Canada between the two World Wars and "an intelligent reflection about literary creation and fiction as a manipulation of reality." Bach thus simultaneously markets the novel for both the "lowbrow" and "highbrow" reader. Robert Saladrigas (2001) in another review with an enticing title ("El precio de la pasión prohibida" / "The price of forbidden passion") speaks about "the amazing skill with which Atwood borders the dangerous reefs of melodrama." Saladrigas situates The Blind Assassin on the border between literary fiction and genre fiction. However, the reviewer contradicts himself by saying that what Atwood is really doing is to play with readers' expectations about genre: "The shrewdly chosen title The Blind Assassin may lead us to think that, given Atwood's penchant for changing registers, she may have decided to try genre narrative. Not in the least. The Blind Assassin is not even a false detective novel." Interestingly, Margaret Atwood (2002), some months later, in a review on Dashiell Hammett ${ }^{124}$ which she wrote for The Guardian, revealed she had always been intrigued by Hammett and may have been influenced by him when writing The Blind Assassin.

Nuria Barrios' text "Dios es verde,"125 ("God is green," review of The Year of the Flood, August 14, 2010) is so far the most recent review of an Atwood book published in the Spanish Press. In addition to some of the usual gambits (allusion to her Nobel candidacy and her literary prizes, including the Prince of Asturias Award, introduction of biographical details), this piece presents some aspects which are unusual in the latest trends of reviewing Atwood in Spain. To start with, it is published in Babelia, the literary supplement of El País, the leading newspaper of

124 In his review of The Blind Assassin, Gurpegui (2001a) finds echoes of Dashiell Hammett in Alias Grace.

125 The title contains an ambiguity because verde in Spanish also means "obscene or indecent" (as in chiste verde: "dirty joke"). 
the country owned by Grupo Prisa, media rival of Atwood's publisher Grupo Zeta. ${ }^{126}$ The novel is hailed in the pre-title of the review as "book of the week." It has as an illustration (as opposed to the usual photograph of Atwood), a photograph of John Hilton's The Road, the film version of Cormac McCarthy's Pulitzer Prize- winning novel of the same title, which is later mentioned in the text as one of the referents of Atwood's The Year of the Flood. It also refers to the same correlates (Brave New World by Huxley, 1984 by Orwell, Farenheit 451 by Bradbury) mentioned in the earlier reviews of The Handmaid's Tale. The lead-in text reads: "The Canadian Margaret Atwood elaborates a funny eco-theology for the post-apocalyptic future in her last novel." The blurb alludes to the sophisticated and funny nature of the novel, and assigns it to different genres (ecology, theology and dystopian fiction), a strategy which makes it potentially attractive to different sectors of readers. ${ }^{127}$ The choice of the reviewer is consistent with the recent tendency of having prestigious writers and intellectuals as critics of Atwood's books. Nuria Barrios, Ph.D., short story writer and poet as well as an award-winning columnist, crafts a particularly well written, informative and coherent review showing that she is what a good reviewer should be - well-read: she appropriately quotes from the Spanish translation of Atwood's poem "Another Visit to the Oracle," included in The Door). She ends, enticingly, with the following words: "The desolate future invented by Atwood projects a possible image of the desolate future which our reality draws. As you read The Year of the Flood you hear yourself laugh, but the sound of that laughter is only too reminiscent of the nervous hilarity provoked by fear" (Barrios, 2010).

\section{The Prince of Asturias Award and Atwood's Spanish Celebrity}

In Spain, Atwood cannot be considered a popular author but, rather, a literary figure. As such, Margaret Atwood has enjoyed preferential treatment by the Spanish media in comparison to other Canadian writers, especially in the last

126 Babelia had not published a review of an Atwood book since the publication of the Spanish translation of Oryx and Crake in 2004. It had never published a review of Atwood's poetry collections even after Atwood had won the Prince of Asturias Award. Whether Babelia does not value Atwood's poetry or whether it is just a matter of rivalry between media groups (Prisa, publisher of El País and Zeta, publishers of Atwood's books) is still undecided.

$\mathbf{1 2 7}$ The marketing strategy seems to have been effective because when I asked for the translation, five days after the publication of the review, in a personal visit to one of the main downtown branches of El Corte Inglés (Spain's most important department store), I was told that they had run out of copies. 
ten years. The publication of most of her recent books has been echoed in the Spanish press by a review of the newly launched novel and an interview. This may have to do with the fact that, as Graham Huggan (2001) argues, Atwood is not just a consecrated writer but also a cultural celebrity and her opinion on global and local -in this case Spanish-issues is highly valued. There is a growing body of critical material on the phenomenon of Atwood's celebrity and how she herself has reflected on it (See Huggan, Becker, York and Moss). Huggan and York agree that the global reach of Atwood is in part due to the quality and readability of her work, but also at least in part due to the way she is marketed by herself, her publishers, the media, and the Canadian Government. Marketing, as Claire Squires (2007) has it, is conceived as a form of representation and interpretation, situated in the spaces between the author and the reader - but which authors and readers also take part in - and surrounding the production, dissemination and reception of texts. ${ }^{128}$

Following the premise that I put forward at the beginning of this chapter - that Atwood's celebrity is another "text"-, the aim of this section is to inquire into how this "text" is produced, disseminated and read in Spain. Atwood's "star text" (Dyer, 1992) is obviously closely linked to her literary texts but functions independently, as I will try to demonstrate. Unlike other Canadian writers who have been published in Spain (Gallant, Munro), Atwood has actively participated in the marketing of both texts - her celebrity and her writing - satisfying her Spanish audiences ${ }^{129}$ with several live performances. She has visited Spain four times, three times on official visits, twice on book-tours (in 1990 for Cat's Eye and 1999 for Alias Grace), and she herself suggested holding a videoconference with the Spanish media when the translation of her poetry collection The Door was presented in Spain.

As expected, the Booker Prize and the Prince of Asturias Award have changed the way in which Atwood is read and marketed by the media in Spain. One of the most visible effects was the appearance in an issue of Babelia, published just in time for the Christmas shopping season, of a two full-page reportage titled "Margaret Atwood: the strength of writing"(December 15, 2001), promoted by the then director of Babelia, María Luisa Blanco. The reportage which featured an interview and a full-page review of The Blind Assassin by Ana María Moix, also featured a sizeable photograph of Atwood placed on the cover page of the

128 Italics in the original.

129 Since the publication of The Year of the Flood in 2009, Margaret Atwood joined the world of online book promotion to reach her English-speaking readers, launching a new and more sophisticated website. She now has her own blog and participates in Twitter and Facebook (run by her publishers) social networks. Atwood's participation in cyberspace has been commented on by the Spanish press (Silió, 2011). Her website (http://margaretAtwood.ca/), however, has no material in languages other than English. 
cultural supplement. In fact, since 2001 the reproduction of her image in Spanish newspapers, literary supplements and magazines has constantly increased. Photographs and caricatures of her have appeared regularly in a variety of publications, of which I will just mention two representative examples. The first is a group of photographs illustrating the first article (on Margaret Atwood) in a series about "great world women writers" (Fresneda, 2007) to appear in the women's magazine Yo Dona, published jointly with El Mundo, in 2007. ${ }^{130}$ Secondly, the reproduction of her image in caricatures, like the one published in El País authored by Agustín Sciamarella (2008) as an illustration of the reportage announcing her as the winner of the Prince of Asturias Award for Letters. ${ }^{131}$ Even more prominently, the literary supplement El Cultural of the national newspaper El Mundo (October 23-29, 2008) used another caricature, in which her face is hardly recognizable, as the cover-page of the issue published the week of the presentation of the Prince of Asturias Awards (Fig. 5.1):

Given that they are often used for politicians or prestigious male authors in Spanish newspapers, the use of caricatures instead of photographs to represent Atwood signifies an unusual degree of consecration - which in Spain is not often granted to a woman writer- and popularization of her figure at the same time.

The story of why and how Atwood was selected for the Asturias Awards interestingly corresponds to elements of her writing that have been exploited in order to market her work more broadly and successfully. According to the minutes of the Jury, Atwood was chosen for the Award for Letters "for her splendid literary oeuvre that has explored different genres with acuteness and irony, and because she cleverly assumes the classical tradition, defends the dignity of women and denounces social injustice. ${ }^{132}$ Unlike the Nobel

130 Yo Dona publishes two photographs of a smiling Atwood, one in colour and another in black and white. In the first one she is wearing a red scarf and matching red lipstick. In the black and white photograph, she is holding her fists out in a victorious attitude, appealing to the young, active, professional woman to whom the magazine is addressed.

131 Sciamarella draws caricatures of significant male politicians and intellectuals for $E l$ País. The newspaper published his caricature of the Spanish writer Miguel Delibes on the occasion of his death on March 12, 2010.

132 To see the Spanish version of the minutes of the jury pertaining to the bestowal of the prize on Atwood, as well as other information about the Foundation and the Awards, see Fundación Príncipe de Asturias, "Margaret Atwood." Given for the first time in 1981, the Prince of Asturias (the heir to the Spanish crown) Awards, sometimes known as "the Spanish Nobel Prizes," are a series of annual prizes given in Spain by the Prince of Asturias Foundation to individuals and/or organizations from around the world who make achievements of universal value in the sciences, humanities, or public affairs. The Jury is made up of members of the Spanish cultural elite endowed with a high symbolic value, like the then President of the Royal Academy of the Spanish Language, Victor García de la Concha, Directors of Literary Supplements and prestigious writers. 


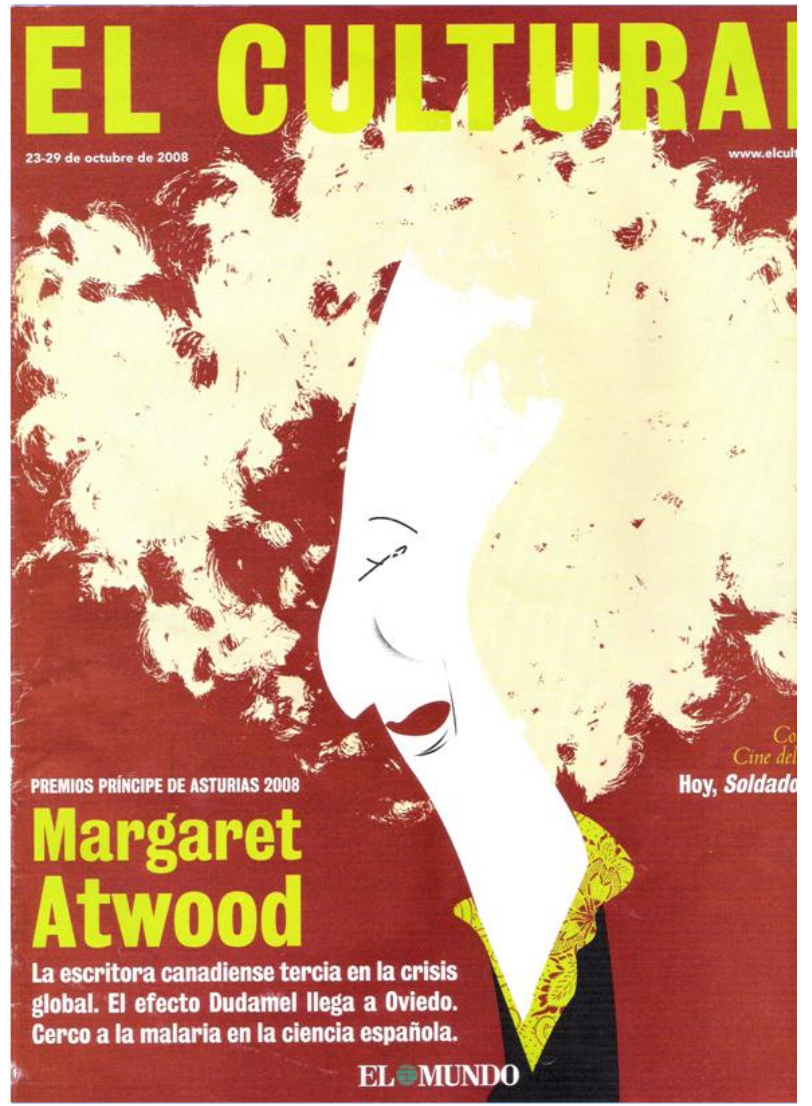

Fig. 5.1 Caricature of Margaret Atwood on the cover page of El Cultural (23-29 October, 2008).

Prize which, as James English (2005) puts it, converts the profits from the manufacture of deadly explosives into a mantle of literary achievement, the Asturias Prizes are associated with a non-lucrative organization whose aim, as specified in its web page, is to strengthen the ties of the Spanish Monarchy with the region of Asturias. ${ }^{133}$ Besides their highly institutional dimension, the Prizes are a mediatic event broadcast by Spanish public television and covered by all Spanish newspapers. In their almost thirty years of history

133 The Foundation's aim does not lack ideological intentions, as Asturias was wellknown for its revolutionary inclinations in the early twentieth century. These resulted in the proclamation of a socialist republic in 1934 - brutally repressed by General Franco which was one of the events leading to the Spanish Civil War in 1936. 
so far, only five women - besides Atwood - have won it. ${ }^{134}$ Doris Lessing, Nélida Piñón and Margaret Atwood are the only writers to have received the Award as a single recipient, a sign of the notorious minority of women among the candidates and winners of this Award. Commenting on the news about Atwood receiving the Prize, the Uruguayan writer Cristina Peri Rossi (2008), now a resident of Barcelona, declared her surprise because "the majority of the candidates were male writers and great prizes are usually bestowed on them" and because "if any of the male members of the jury of the Prince of Asturias Award has in effect read Margaret Atwood carefully and voted for her, then something must have changed in this country." Peri Rossi is referring to the subordinate position women had under Franco's dictatorship which has later transformed itself into a veiled inequality of rights which the present Ministry of Health, Social Policy and Equality ${ }^{135}$ of the Socialist Government is trying to address.

In spite of the official defence of equality between men and women, a certain negative bias against feminism still lurks in some conservative Spanish media. In these media, defining Atwood as a "defender of women's rights" often means to classify Atwood as a "feminist writer." As Fiona Tolan (2007) points out, Atwood has repeatedly been pressured to support and endorse feminist politics and to explicitly associate her work with the movement. She has repeatedly refused to be drawn to into such an allegiance. In an early interview with Margaret Kaminski, she provided the following description about The Edible Woman, often considered one of her most feminist novels: "I don't consider it feminism. I consider it social realism" (Kaminski, 1990). In a later conversation with Rebecca Garron, she still resists having the label "feminist" attached to her as a writer: "In other words, if you're doing something because you think you should, whatever it is, it's likely to be bad. If there is no real energy behind it, it becomes billboard, it becomes dutiful. And that goes for anything, including feminism [...]. The thing may be a good cause, and as citizens we may deeply approve of it, but if as writers we don't feel organically inspired to write about it, we shouldn't" (Garron, 2006).

134 The Spanish novelist Carmen Martín Gaite shared it with her countryman poet José Ángel Valente in 1988; Fatima Mernissi (a Moroccan feminist writer) shared it with Susan Sontag in 2003; Doris Lessing obtained it 2001. The last woman to win it before Atwood was Nélida Piñón (a Brazilian writer of Spanish descent) in 2005. Doris Lessing, the last English-speaking author to receive the Asturias Award before Atwood, was awarded the Nobel Prize in 2007, thus confirming that some Asturias awardees are afterwards recipients of the Nobel.

135 Between 2008 and October 2010, there was a Ministry of Equality. The merging of the three ministries occurred during the recession. 
Among certain sectors of the Spanish public - those who have contributed to perpetuating the aforementioned gender inequality - this association with feminism can be considered what Lorraine York (2006) calls a disabler of celebrity status. Her alleged condition as a feminist writer has been, and still is, a site of contestation for the Spanish critics, especially - but not only - the male ones, who do not think the adjective suitable for Atwood. Luis Marigómez (2000) remarks that "she has a feminist point of view, [but] it is not radical." Gurpegui (1998) observes that to catalogue Atwood as a feminist author is to reduce the meaning of her work. Antonio Colinas, a Spanish poet and member of the jury of the Prizes, states that her vantage point about the feminine is not the result of a mere topical feminism (Colinas, 2008). Among the female critics, there also seems to be a divergence of opinions. Lourdes Ventura (2008) calls her a "protofeminist," and Peri Rossi (2008) a "feminist post lettre."

Before ending this section, I would like to illustrate how Atwood's ideas have often been manipulated by the Spanish press. With reference to her categorization as a "feminist writer," let us consider an interview published in El Mundo on the day of the announcement of the Asturias Award. The article had the following titillating title: "We should be judged by our merits. And without our skirts!" (Alemany, 2008). The elliptical form of Atwood's statement ${ }^{136}$ insisting on her old argument that she does not believe in the distinction between men and women writers, but only between good and bad writers may provoke all kinds of comical interpretations, surely unintended by Atwood who only wanted to reiterate her dissociation of gender and good literature. In the lead-in to the interview, Atwood is hailed as a "veteran of feminism," and when asked by interviewer Lluis Alemany whether she considered feminism (or its literature) as part of official culture, Atwood responded that she would not say she writes feminist literature as that would sound too much like a political programme. This statement was turned into another headline, printed on the cover page of the newspaper itself: "Feminism? it sounds too much like a political programme"(Alemany, 2008). Notwithstanding the headline, throughout the interview Atwood bluntly attacks a number of stereotypes about men and women and insists that she does not believe that being a woman is an obstacle for writing.

Let me provide a final example from her latest visit to Spain, when she came to be presented with the Prince of Asturias Award in 2008. A current affair at the time was the proposal of the internationally famous Spanish Judge Baltasar

136 What Atwood actually said was "Women writers should be judged by their merits. And do not let skirts interfere with these judgements, if possible." 
Garzón ${ }^{137}$ to pass judgement on the crimes committed by Franco during the Spanish Civil War and his subsequent dictatorial regime. Garzón labelled the dictator's crimes as "genocide." Asked about this issue by several right-wing Spanish newspapers (El Mundo, La Razón, and ABC) on June 23, 2008, Atwood responded: "I am not sure that genocide is the most appropriate label. The war was fought between citizens of the same country who only had different political views ... In addition, it is perhaps already too late for that. Most of the people who participated in that war are already dead (Lucas, 2008). Javier Ors (2008) in La Razón reproduces Atwood's answer in similar terms, while adding a comment about the role of Canadians who came to fight in the Spanish Civil War. Antonio Astorga (2008) also includes Atwood's opinion in the lead-in of his article published in $\mathrm{ABC}$.

These declarations seem unexpected in someone like Atwood, who has permanently condemned political violence and defended human rights. Furthermore, since her view coincides with the take of right-wing sectors of Spanish society on this matter, it would not be too far-fetched to conclude that these three newspapers could have taken advantage of Atwood's reputation as a public intellectual to support their ideological position. Nevertheless, these headlines could also be taken as examples of her ability to be provocative with regard to a current event. To conclude this section, I would like to state that, in spite of the way in which the Spanish media have used Atwood's statements for their purposes, I agree with Graham Huggan that there is something of a staged controversiality surrounding Atwood. She is what Huggan (2001) calls an "establishment subversive," with an ability to pick current topics and offer a provocative slant.

137 Garzón came to international attention in 1998 when he issued an international warrant for the arrest of former Chilean President, General Augusto Pinochet, for the alleged deaths and torture of Spanish citizens. Since the first revision of this chapter (July 2011) until the second (February 2012), Garzón has been accused of various irregularities and finally indicted on three different counts relating to a fraud trial, the investigation of Francoist crimes and taking bribes. Although he has been acquitted of exceeding his authority in investigating the crimes of the Francoist era, he has been accused of illegal wiretapping of conversations between suspects and their lawyers in a well-known case of political corruption (Caso Gürtel). The trial judge described this act as appropriate to a dictatorship and sentenced him to eleven years disqualification from judicial activity. 


\section{Conclusions: the Future of Atwood's Writing in Spain}

Like most Canadian writers, Atwood was imported into Spain as a marketable author of certain kinds of genre fiction (science-fiction, feminine novel), but in contrast to most of her countrymen/women - except, perhaps, Alice Munroshe has increasingly accumulated symbolic capital. As has been the case with other Canadian writers, the reediting and reprinting of Atwood's works has been linked to the progressive accumulation of prizes and indexes of canonization, like Harold Bloom's famous inclusion in his Western canon. Prizes play a crucial role in the interaction between genre and the marketplace. They also influence notions of cultural value and literariness (Squires, 2007) but I am of the same view as Belén Martín-Lucas, ${ }^{138}$ prizes neither guarantee durable favour among readers nor permanent inclusion in the literary canon. Literary taste, in fact, does not always depend on prizes. For Bourdieu (1984), all taste in literature is an effect of prior determinants and class position, since training and one's education classify readers into groups that favour one kind of literature over another. Skilfully addressing different potential audiences, when interviewed by the Spanish press on the day that news about the Asturias Prize broke out, her Spanish editor Ana Maria Moix (2008a) spoke about her cultural capital to the high/middlebrow readers of El País: "Atwood's books do not reach spectacular sales but the reader appreciates the exquisite quality of her prose, her exquisite sensibility, her unbendable irony. But on the same day, Moix (2008b) also described the Canadian writer to the lowbrow audience of 20 Minutos "as a writer of prestige who had not fully reached the great public." Moix (2008a) is right to say that in Spain Atwood is supported by a group of personalities from dominant cultural and political groups, whose allegiance adds to her growing symbolic capital. However, in spite of the Asturias Prize, she is still unknown to the average Spanish reader who feeds on best-sellers.

Atwood cannot be considered a bestselling author in Spain at the moment. However, all her books - with the exception of her poetry collections - were translated into Spanish with the aim of becoming best-sellers. As Bourdieu (1999) rightly observes, "translation is a pre-eminently financial investment that always aims, openly or not, at the production of best-sellers. If we follow Connor's 1996 definition of literary fiction ("Literary fiction is usually defined by negation - it is not formula fiction or genre fiction, not mass market or bestselling fiction - and, by substraction, it is what is left once most of the

138 See chapter 3 of this collection. 
conditions that obtain in contemporary publishing are removed") Atwood could not be considered a literary author. She is well-known for using the strategies of formula fiction and genre fiction in her novels and she takes part in all the resources of contemporary publishing and book marketing. Among her English-speaking readers, the dissemination of her works and presence through social networks like Twitter ${ }^{139}$ (in which she participates directly) and Facebook (run by her publishers) is well-known. Social networks have still not been used by her Spanish publishers to publicize her writing, but the number of spontaneous Spanish blogs and websites about her is growing steadily.

Whereas Atwood's online Spanish popularity is a relatively new phenomenon, as a public intellectual she has been respected for a while. I have shown how she is quoted and appropriated by media of diverse political tendencies but, most prominently, some of her cutting-edge societal concerns -defence of women's rights and social justice in general, sustained economic development and ecological preoccupations) (Somacarrera, 2012) coincide with the ideological values of the Spanish Socialist Party. To say that she could have been coopted is, no doubt, a controversial statement. However, evidence for the solid institutional support she has received from the Spanish Socialist government can be found, for example, in the fact that her candidacy to the Asturias Award, questioned by some members of the jury who wanted a Spanish-speaking winner, was backed by the former General Director of Book Affairs, Archives and Libraries of the Spanish Ministry of Culture, Rogelio Blanco. César Antonio Molina, writer, director of the Círculo de Bellas Artes and Minister of Culture at the time that Atwood received the prize, could also be counted among her supporters. ${ }^{140}$ That institutional support for Atwood in Spain has come even from the highest political spheres is proved by the fact that the Vice President of the former Spanish Government, Ma Teresa Fernández de la Vega, once quoted from Atwood's acceptance speech for the Asturias Prize. Atwood's words were quoted by Fernández de la Vega in a public intervention on the occasion of an agreement between the Ministry of Presidency and the Prince of Asturias Foundation. The Vice President used Atwood's words from her acceptance speech to speak about the prestige of the Asturias Prizes and of the importance of creativity for human beings. ${ }^{141}$

139 Atwood has recently been mentioned in an article in El Cultural about writers who use Twitter to communicate with their readers (Trubek, 2012).

140 César Antonio Molina's wife is Mercedes Monmany, regular columnist of literary supplements and a well-known commentator and admirer of Atwood.

141 Gobierno de España, "Intervención de la Vicepresidenta Primera del Gobierno." 
Five years after the Asturias Prize, Atwood's Spanish followers face new questions as another publisher (Lumen), with higher symbolic capital, continues to publish her work: Will internet social networks and blogs make her more popular? How will her future books be distributed? As for the channel of dissemination, Margaret Atwood latest works have been distributed as e-books on the internet, showing the author's conviction that technological advances in publishing are here to stay and are the best way to reach a global audience. Genre-wise, since the beginning of the second decade of the twenty-first century, Margaret Atwood has focused on writing speculative short fiction and essays is about science fiction (In Other Worlds: SF and the Human Imagination). This collection of essays (still unedited in Spain) and the three episodes of the Positron trilogy ("I'm starved for you," "Choke Collar" and "Erase me") speak of Atwood's return to the kind of dystopian writing which captured her first Spanish readers in the late eighties and will surely capture them again. ${ }^{142}$

142 At the time of revising this chapter (March 2012) Lumen (Random House Mondadori) has already released Atwood's first e-book in Spanish, Tengo hambre de ti/I'm Starved for You, the first part of the Positron trilogy, which has been advertised in a tweet in Spanish in Atwood's Tweetwood. I venture to anticipate that Silvia Querini's (her new Spanish editor) talent for negotiation and communication (Lozano, 2011) will raise the sales of Atwood's books in Spain. 